\title{
Meconium ileus equivalent in older patients with cystic fibrosis
}

\author{
J G HANLY, M X FITZGERALD
}

\begin{abstract}
Meconium ileus equivalent is one of the lesser known manifestations of cystic fibrosis, and occurs most often in older patients. With the improved overall survival of patients with cystic fibrosis, one would expect to see this condition more often in the future. Of 53 patients attending our cystic fibrosis clinic for adolescents and adults, eight had experienced a total of 25 episodes of meconium ileus equivalent. Recurrent attacks occurred in seven patients, of whom four had at least four separate, well documented episodes: these episodes were associated with obvious recognised precipitating factors in only three patients. All patients responded to appropriate medical treatment with acetylcysteine or sodium diatrizoate, including three who had previously undergone surgery for meconium ileus equivalent elsewhere. Controversies remain, however, concerning the role of prophylactic medical management with acetylcysteine, sodium diatrizoate, and pancreatic supplements.
\end{abstract}

\section{Introduction}

Gastrointestinal symptoms occur in $85 \%$ to $90 \%$ of cases of cystic fibrosis, ${ }^{1}$ and one of the lesser known of these is meconium ileus equivalent. This term is used to describe partial or complete bowel obstruction, wh:ch results from abnormally viscid mucofaeculent material in the terminal ileum and right colon, where the faecal stream is normally liquid. It occurs outside the neonatal period, often in older patients, ${ }^{2}$ and usually presents as recurrent abdominal pain, intestinal obstruction, or a palpable caecal mass. To date there has been a paucity of published reports on the aetiology, clinical features, and specific management of the condition. ${ }^{3}{ }^{4}$ We describe eight patients with meconium ileus equivalent, seven of whom had recurrent attacks, and review the controversial subjects of diagnosis and treatment.

\section{Patients and methods}

The case notes and $x$ ray films of 53 patients attending the adolescent and adult cystic fibrosis clinic at St Vincent's Hospital were reviewed. Where possible, notes relating to admissions to other hospitals were also examined. Criteria for the diagnosis of cystic fibrosis included

St Vincent's Hospital, Dublin 4

J G HANLY, MB, MRCPI, registrar in respiratory medicine

$M$ X FITZGERALD, MD, FRCP, professor of medicine (University College, Dublin)

Correspondence to: Dr J G Hanly. typical clinical features, and a raised sweat sodium concentration of greater than $70 \mathrm{mmol}(\mathrm{mEq}) / \mathrm{l}$. Meconium ileus equivalent was diagnosed if at least one of the following criteria was fulfilled: (a) recurrent abdominal pain, due to well documented faecal impaction or constipation; (b) recurrent palpable caecal masses; or (c) complete intestinal obstruction, caused by firm faecal material in the terminal ileum or right colon, or both.

Patients with asymptomatic palpable caecal masses were observed without active intervention. All patients with intestinal obstruction or persistent severe colicky abdominal pain were managed medically. They received acetylcysteine $1.22 \mathrm{~mol} / 1(20 \mathrm{~g} / 100 \mathrm{ml}), 10 \mathrm{ml}$ four times daily, given as a sweet drink to mask the unpalatable taste, and acetylcysteine $1.22 \mathrm{~mol} / 1(20 \mathrm{~g} / 100 \mathrm{ml}), 50 \mathrm{ml}$ administered as an enema, with $50 \mathrm{ml}$ of water, one to four times a day, depending on the degree of intestinal obstruction. On one occasion when intestinal obstruction was very severe sodium diatrizoate was added, $30 \mathrm{ml}$ three times a day orally, and $100 \mathrm{ml}$ three times a day as an enema. Patients continued their usual dose of pancreatic supplements, were kept well hydrated with intravenous fluids, and had analgesics for pain control. We did not use nasogastric intubation routinely, although this may be helpful in some cases of severe obstruction and avoids the unpleasant taste of acetylcysteine.

\section{Results}

Eight of the 53 patients (five boys, three girls) were found to have meconium ileus equivalent. The table summarises the findings. Age at initial presentation ranged from $1 \frac{1}{2}$ to 17 years, and all but one (case 8 ) had recurrent attacks. Modes of presentation included colicky abdominal pain (eight patients), palpable caecal mass (four patients), clinical and radiological evidence of intestinal obstruction (three patients), and intussusception (one patient). Radiological abnormalities were found in all six patients whose $x$ ray films were available for review; these abnormalities included bubbly faecal material in the large bowel ${ }^{1}$ (six patients), multiple air-fluid levels in the small bowel (three patients), and intussusception (one patient). No precipitating factors were identified in five patients. In three patients potential factors included respiratory tract infections (cases 6 and 8), immobilisation (cases 5 and 6), and sudden withdrawal of pancreatic supplements with concurrent administration of diphenoxylate (case 8).

Although all patients were treated medically by us, three patients had undergone operations without a trial of medical treatment before referral to our unit: one (case 1) for exploration of an abdominal mass, another (case 2) for relief of intestinal obstruction, and a third (case 5) for intussusception on two separate occasions. Despite surgical treatment, all three patients continued to have recurrent episodes of meconium ileus equivalent, which responded to appropriate medical treatment. The major complication was intussusception, which occurred twice in one month in one patient (case 5) after a prolonged attack of unequivocal meconium ileus equivalent, prompting surgical intervention on both occasions.

On medical treatment alone, there was symptomatic improvement in all cases in less than 24 hours, usually coinciding with the passing of stools per rectum. Some patients, however, continued to have abdominal pain for five days after the start of treatment. As the obstruction resolved, the frequency of oral medications and enemas was reduced and eventually stopped. The duration of treatment with 
Clinical features of eight patients with meconium ileus equivalent

\begin{tabular}{|c|c|c|c|c|c|c|c|c|c|c|c|c|}
\hline \multirow[b]{2}{*}{$\begin{array}{l}\text { Case } \\
\text { No }\end{array}$} & \multirow[b]{2}{*}{ Sex } & \multirow[b]{2}{*}{$\begin{array}{c}\text { Age at } \\
\text { presentation } \\
\text { (years) }\end{array}$} & \multicolumn{7}{|c|}{ Symptoms at presentation } & \multirow[b]{2}{*}{$\begin{array}{l}\text { Precipitating } \\
\text { factors }\end{array}$} & \multirow[b]{2}{*}{ Treatment } & \multirow[b]{2}{*}{ Remarks } \\
\hline & & & $\underset{\text { pain }}{\text { Abdominal }}$ & 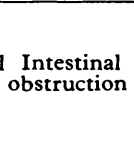 & $\begin{array}{l}\text { Caecal } \\
\text { mass }\end{array}$ & $\begin{array}{l}\text { Intussus- } \\
\text { ception }\end{array}$ & $\begin{array}{c}\text { Multiple } \\
\text { fluid } \\
\text { levels in } \\
\text { small } \\
\text { bowel }\end{array}$ & $\begin{array}{c}\text { Colonic } \\
\text { faecal } \\
\text { material } \\
\text { with } \\
\text { bubbly } \\
\text { appearance }\end{array}$ & $\begin{array}{c}\text { Intussus- } \\
\text { ception } \\
\text { (barium } \\
\text { enema) }\end{array}$ & & & \\
\hline 1 & $M$ & 910 & + & & + & & & & & None & $\begin{array}{l}\text { Surgery } \\
\text { Medical }\end{array}$ & $\begin{array}{l}\text { MIE recurred } \\
\text { one year } \\
\text { after } \\
\text { surgery }\end{array}$ \\
\hline 2 & $M$ & 11245 & + & + & & & + & + & & None & $\begin{array}{l}\text { Surgery } \\
\text { Medical }\end{array}$ & $\begin{array}{l}\text { Murgery } \\
\text { MIE recurred } \\
\text { after } \\
\text { surgery. } \\
\text { Cirrhosis }\end{array}$ \\
\hline $\begin{array}{l}3 \\
4\end{array}$ & $\begin{array}{l}M \\
M\end{array}$ & $\begin{array}{lllll}15 & 16 & 19 & 20 \\
7 \frac{1}{2} & 9 & 10 & 11 & 15 \\
16 & & & & \end{array}$ & + & + & $\begin{array}{l}+ \\
+\end{array}$ & & + & $\begin{array}{l}+ \\
+\end{array}$ & & $\begin{array}{l}\text { None } \\
\text { None }\end{array}$ & $\begin{array}{l}\text { Medical } \\
\text { Medical }\end{array}$ & \\
\hline 5 & $\mathrm{~F}$ & $\begin{array}{cccc}15 & 18 \frac{1}{2} & 19 & 20 !\end{array}$ & + & & & + & & + & + & Immobilisation & $\begin{array}{l}\text { Surgery } \\
\text { Medical }\end{array}$ & $\begin{array}{l}\text { Continues to } \\
\text { have MIE } \\
\text { four years } \\
\text { after } \\
\text { operation }\end{array}$ \\
\hline 6 & $\mathrm{~F}$ & 1516 & + & & & & & + & & $\begin{array}{l}\text { Respiratory tract infections. } \\
\text { Immobilisation }\end{array}$ & Medical & \\
\hline 7 & $\mathrm{~F}$ & 1718 & + & & + & & & & & None & None & $\begin{array}{l}\text { Spontaneous } \\
\text { resolution } \\
\text { of } M I E\end{array}$ \\
\hline 8 & $M$ & 16 & + & + & & & + & + & & $\begin{array}{l}\text { Respiratory tract infection. } \\
\text { Sudden withdrawal of } \\
\text { pancreatic supplements. } \\
\text { Diphenoxylate. }\end{array}$ & Medical & \\
\hline
\end{tabular}

MIE $=$ Meconium ileus equivalent

acetylcysteine and sodium diatrizoate varied from three to eight days. We did not continue these agents once the acute attack had resolved. For prophylactic medical management, we asked patients to avoid potential precipitating factors, particularly drugs that might promote constipation, to maintain a high fluid intake and high dietary roughage, and to take regular pancreatic enzyme supplements. Occasionally a stool softener such as lactulose was added.

\section{Discussion}

The term meconium ileus equivalent encompasses a broad range of clinical manifestations arising from partial or complete intestinal obstruction. It may be classified into three groups, based on the mode of presentation: (a) recurrent abdominal pain, secondary to well documented faecal impaction or constipation; (b) recurrent palpable caecal masses, which may resolve spontaneously; and (c) complete intestinal obstruction, caused by abnormally viscid and impacted intestinal contents.

Patients with complete intestinal obstruction almost invariably have an acute onset of symptoms; whereas those with other symptoms have a subacute presentation. The prevalence of meconium ileus equivalent in patients with cystic fibrosis is difficult to determine but is said to be from $1 \%$ to $10 \%{ }^{3}$ In our series it was $15 \%$.

The clinical and radiological features of the condition (figure) may be explained by the abnormal consistency of the bowel contents in the terminal ileum and right colon. These are semisolid or solid and extremely viscid compared with the liquid faecal stream normally found in this part of the bowel. ${ }^{5}$ Material may accumulate to form a painless mass, or cause partial or complete obstruction of the bowel lumen.

The reason for the abnormal bowel contents is not entirely clear, but they may result from tenacious intestinal mucus, ${ }^{6}$ abnormal intestinal mucoproteins, ${ }^{7}$ and pancreatic insufficiency. ${ }^{4}$ Hallberg described a patient with obstruction whose bowel wall was coated with a thick adherent mucilaginous membrane, ${ }^{8}$ and Snyder et al reported three similar cases, in whom there was a thick layer of mucus adhering to the intestinal mucosa. ${ }^{6}$ This abnormal mucus originates from hypertrophied intestinal glands, ${ }^{4}$ many of which are distended with inspissated mucus. Additionally, the duodenal contents of older patients with cystic fibrosis contain abnormal mucoproteins, which are water insoluble ${ }^{7}$ and increase the viscosity of bowel contents. Pancreatic insufficiency may also contribute, because sudden withdrawal of pancreatic supplements may precipitate meconium ileus

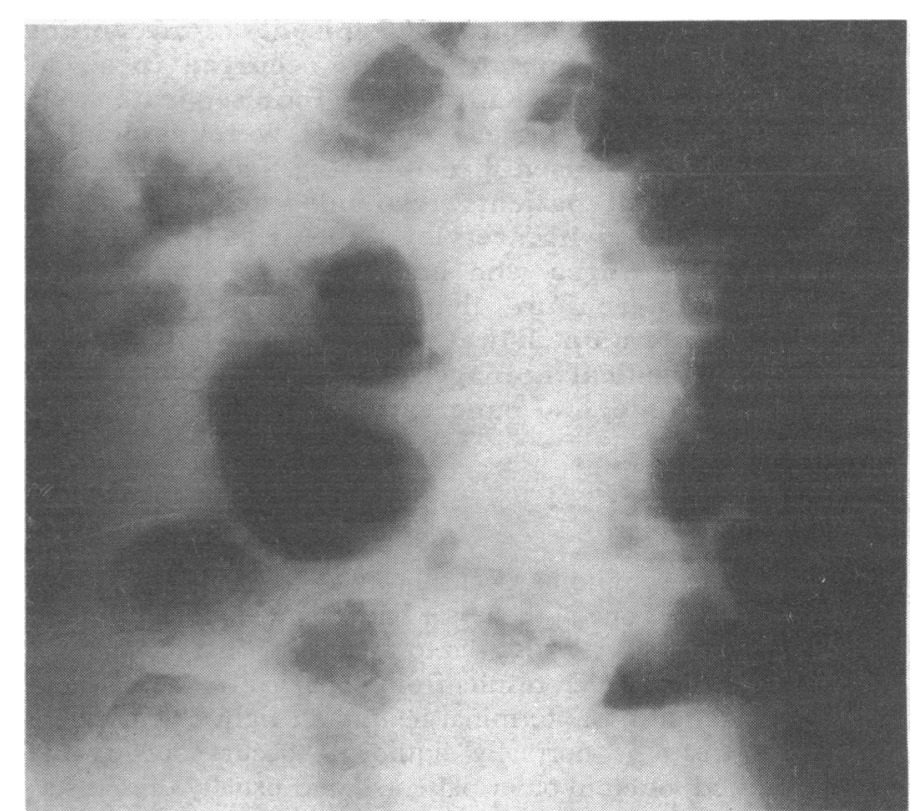

Abdominal $x$ ray film showing multiple air-fluid levels within the dilated small bowel indicating obstruction. Masses of faecal material filled with air are seen within ascending, descending, and sigmoid colon. This patient had a severe episode of meconium ileus equivalent, but made a full recovery after appropriate medical treatment.

equivalent, and their reintroduction helps to relieve the obstruction. ${ }^{9}$ Pancreatic enzymes have been shown to act on the intestinal mucus to release water soluble fragments, thereby reducing viscosity. ${ }^{10}$

The commonest presentation in our group was abdominal pain, with or without intestinal obstruction, and this is similar to the findings of other workers. ${ }^{13}$ Clinical and radiological examination must be used to eliminate other causes of abdominal pain in this age group, such as simple colonic constipation and intussusception without meconium ileus equivalent. A palpable faecal mass in the right lower quadrant may accompany abdominal pain or occur independently of it, in which case it must be distinguished from other causes of masses in this area such as an appendix abscess and Crohn's disease. Attacks may occur spontaneously or be precipitated by a number of factors, 
particularly sudden withdrawal of pancreatic supplements. ${ }^{2}$ This precipitated attacks in one of our patients; others followed immobilisation, respiratory infections, and use of antidiarrhoeal agents. There is a tendency for meconium ileus equivalent to recur, ${ }^{21}$ and in our group seven out of eight patients had more than one attack, with a total of 25 episodes in all. Intussusception ${ }^{12}$ and, less frequently, volvulus ${ }^{13}$ are the main complications. One patient (case 5) in our group had two episodes of intussusception, which required surgical intervention on both occasions after radiological contrast studies confirmed the diagnosis.

The treatment of choice for uncomplicated cases of meconium ileus equivalent is medical. Acetylcysteine is a mucolytic agent, which reduces viscosity by cleaving disulphide bonds in mucoprotein molecules. ${ }^{14}$ This usually gives speedy relief of intestinal obstruction, ${ }^{15} 16$ and is commonly used in concentrations of $0 \cdot 6-1 \cdot 2 \mathrm{~mol} / \mathrm{l}(10-20 \mathrm{~g} / 100 \mathrm{ml})$ three times daily, by mouth and by enema. ${ }^{4}$ The recommended volume of acetylcysteine varies from 5 to $30 \mathrm{ml}$ given three to six times daily. ${ }^{416} \mathrm{We}$ found our regimen of $10 \mathrm{ml}$ four times daily to be effective. All our patients showed a symptomatic improvement within 24 hours, coinciding with the passage of stools per rectum. In cases of complete intestinal obstruction, or when acetylcysteine alone is ineffective, sodium diatrizoate is sometimes added to this regimen. ${ }^{3}$ This radio-opaque aqueous solution acts through its detergent and hypertonic properties and may be given by mouth or by enema. In addition, the patient's pancreatic supplements are continued and a high fluid intake is maintained.

Surgical intervention is only warranted when a reasonable trial of medical treatment has failed to relieve obstruction, or when complications such as intussusception, or volvulus occur. Surgery must be avoided if at all possible, however, because of poor respiratory function. Furthermore, excessive manipulation of the bowel during operation (which is often necessary due to the abnormal faecal content) may predispose to the formation of adhesions. ${ }^{2}$ In addition, it is often impossible to remove tirmly adherent inspissated bowel contents without resecting a length of bowel.

The correct prophylactic management of patients with meconium ileus equivalent is less certain. Some authors have suggested that patients should be maintained on a regular oral regimen of acetylcysteine. ${ }^{4}$ Acetylcysteine is, however, very expensive and highly unpalatable, although the unpalatability may be partly overcome by chilling and mixing with a sweet drink. In addition, no data clearly show that acetylcysteine or, indeed, sodium diatrizoate is more effective than other simpler and less expensive therapeutic agents such as laxatives and dietary roughage. Consequently, our policy has been to advise patients to avoid precipitating factors, to maintain a high fluid intake and dietary roughage, and, if necessary, to take stool softeners such as lactulose. It is clear that a well controlled study is required to assess accurately the role of acetylcysteine, sodium diatrizoate, and other modalities of treatment in the acute and chronic management of this troublesome and increasingly common manifestation of cystic fibrosis.

\section{References}

${ }^{1}$ Park RW, Grand RJ. Gastrointestinal manifestations of cystic fibrosis: a review. Gastroenterology $1981 ; 81: 1143-61$.

2 di Sant' Agnese PA, Davis PB. Cystic fibrosis in adults, 75 cases and a review of 232 cases in the literature. $A m \mathcal{F}$ Med 1979;66:121-32.

${ }^{3}$ Matseshe JE, Go VLW, Di Magno EP. Meconium ileus equivalent complicating cystic fibrosis in post neonatal children and young adults. Gastroenterology 1977;72:732-6.

${ }^{4}$ Hodson ME, Mearns MB, Batten JC. Meconium ileus equivalent in adults with cystic fibrosis of the pancreas : a report of six cases. $\mathrm{Br} \mathrm{Med} \mathcal{F}$ 1976;ii :790-1.

${ }^{5}$ Mullins F, Talamo R, di Sant' Agnese PA. Late intestinal complications of cystic fibrosis. $\mathcal{F} A M A 1965 ; 192: 741-6$.

${ }^{6}$ Snyder WH, Gwinn JL, Landing BH, Asay LD. Faecal retention in children with cystic fibrosis. Report of three cases. Pediatrics $1964 ; 34$ : 72-7.

7 di Sant' Agnese PA, Dische Z, Danilczenko BS. Physicochemical differences of mucoproteins in duodenal fluid of patients with cystic fibrosis of the pancreas and controls. Pediatrics 1957;19:252-60.

${ }^{8}$ Hallberg D. Mucoviscidosis ileus. Acta Chir Scand 1964;128:201-9.

${ }^{9}$ Birse EL. Intestinal obstruction as a late complication of fibrocystic disease of the pancreas. $B r$ Med $\mathcal{f} 1956$;ii :286.

${ }_{10}$ Harries JT. Meconium in health and disease. Br Med Bull 1978;34:75-8.

11 Shwachman H, Kowalski M, Khaw KT. Cystic fibrosis: a new outlook, 70 patients above 25 years of age. Medicine $1977 ; 56: 129-49$.

${ }^{12}$ Holsclaw D, Rocmans C, Shwachman H. Intussusception in patients with cystic fibrosis. Pediatrics $1971 ; 48: 51-8$.

${ }^{13}$ Larsson Y. The islets of Langerhans in pancreatic cystic fibrosis. Pediatrics $1958 ; 21: 893-902$.

14 Sheffner A. The reduction in vitro in viscosity of mucoprotein solutions by a new mucolytic agent n-acetylcysteine. Ann NY Acad Sci 1963; $106: 288-97$.

${ }^{15}$ Lillibridge CB, Docter JM, Eidelman S. Oral administration of n-acetyl cysteine in the prophylaxis of "meconium ileus equivalent." $f$ Pediatr $1967 ; 71: 887-9$.

${ }^{16}$ Sigler RM, Reeves HH, Lynn HB, Burke EC. Cystic fibrosis with faecal retention (meconium ileus equivalent): report of two cases. Mayo Clin Proc 1965;40:477-80.

(Accepted 9 February 1983)
Does taking babies "swimming" in the first few weeks of life reduce the risk of cot deaths?

The theory that swimming may be protective against cot deaths comes from the application of a "diving reflex" possessed by many vertebrates, but relatively weak in man. Submersion causes bradycardia and peripheral vasoconstriction, protecting the blood supply to the heart, lungs, and brain in order to avoid asphyxiation. As it is hypothesised that some cot deaths are triggered by recurrent episodes of hypoxia, regular exercise of this reflex while awake might condition the baby to survive prolonged apnoea while asleep. This is speculation. Investigations of cot deaths nearly always produce clues to the cause of death which would be expected to override any protection. The dangers of supervised bathing in the first three months of life (the age necessary if benefit were to be gained) are poorly documented because the enthusiasm is such a recent phenomenon. Hypothermia or infection are obvious possibilities. A 10 month old child became apnoeic and nearly died of water intoxication without immediate appreciation that he had swallowed excessive amounts during a swimming lesson. ${ }^{1}$ If this were to happen to only one in 500 babies, in several thousand swims, the risk would outweigh any possible benefit.-A N STANTON, consultant paediatrician, Scarborough.

Goldberg GN, Lightner ES, Morgan W, Kemberling S. Infantile water intoxication after a swimming lesson. Pediatrics $1982 ; 70: 599-600$.
Is prostatic hypertrophy often accompanied by a diminution in sexual activity? If so is it connected with reduced circulating androgens? Is there any place in simple (non-malignant) prostatic hypertrophy for prophylactic androgens and possibly palliative androgens when urinary symptoms develop?

There is no scientific evidence to support the "suggestion" that sexual activity is diminished in prostatic hypertrophy. The only observation supporting this so far as I know is that in dogs prostatic hypertrophy seems to occur more often in animals kept secluded as domestic pets while at the same time prostatic hypertrophy is much less common in the pi-dog that is allowed to roam. This may suggest that diminished sexual activity might possibly be one factor in the

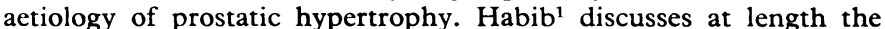
factors controlling abnormal growth of the prostate, and any reduction in circulating androgens is not specifically associated with prostatic hypertrophy. As regards the prophylactic management of so-called benign prostatic hypertrophy, the treatment with androgens or oestrogens has never proved to be of any lasting value.-J P MITCHELL, honorary professor of surgery (urology), Bristol.

Habib FK. Factors controlling abnormal growth of the prostate. In: Chisholm GD, Williams DI, eds. Scientific foundations of urology. 2nd ed. London: William
Heinemann, Medical, 1982:499-505. 